Musters, A.M., Repping, S., Korevaar, J.C., Mastenbroek, S., Limpens, J., Veen, F. van der, Goddijn, M. Pregnancy outcome after preimplantation genetic screening or natural conception in couples with unexplajne recurrent miscarriage: a systematic review of the best available evidence. Fertility and Sterility: 2011,95(6) 2153-2157

\begin{tabular}{|l|l|}
\hline Postprint Version & 1.0 \\
\hline Journal website & http://www.fertstert.org/article/S0015-0282(10)02964-X/abstract \\
\hline Pubmed link & http://www.ncbi.nlm.nih.gov/pubmed/21215967 \\
\hline DOI & $10.1016 /$ j.fertnstert.2010.12.022 \\
\hline
\end{tabular}

This is a NIVEL certified Post Print, more info at http://www.nivel.eu

\title{
Pregnancy outcome after preimplantation genetic screening or natural conception in couples with unexplained recurrent miscarriage: a systematic review of the best available evidence
}

\author{
AnNa M. Musters M.D.A, , , SJoerd RepPing Ph.D.a, Johanna C. KoreVAar Ph.D.b, SebastiaAn \\ Mastenbroek M.Sc.A, Jacqueline Limpens Ph.D.c, Fulco VAn DER VeEn M.D., Ph.D.A, MARiëtTe \\ GODDIJN M.D. PH.D.A \\ a Center for Reproductive Medicine, Department of Obstetrics and Gynecology, University of Amsterdam, \\ Amsterdam, the Netherlands \\ b Department of Clinical Epidemiology, Biostatistics and Bioinformatics, Academic Medical Center, \\ University of Amsterdam, Amsterdam, the Netherlands \\ c Medical Library and Dutch Cochrane Center, Academic Medical Center, University of Amsterdam, \\ Amsterdam, the Netherlands
}

The objective of this systematic review was to assess live birth rates and miscarriage rates after preimplantation genetic screening or natural conception for unexplained recurrent miscarriage. There were no randomized controlled trials or comparative studies found on this topic. Until data from randomized controlled trials become available, this review summarizes the best available evidence of the efficacy of preimplantation genetic screening vs. natural conception.

Recurrent miscarriage (RM), defined as two or more miscarriages, affects approximately $5 \%$ of all couples (1). Current diagnostic procedures can identify etiologic factors in approximately $50 \%$ of these couples (1). Unexplained RM is a distressing condition for the affected couple and a frustrating problem for the clinician, because there is no effective therapy for these couples as of yet. Some authors have proposed preimplantation genetic screening (PGS) for couples with unexplained RM. The rationale behind the use of PGS in cases of unexplained RM is that aneuploidy of the embryo may be the cause of the RM (2-6) .

Data from the European Society of Human Reproduction and Embryology preimplantation genetic diagnosis consortium shows an increase of PGS cycles for couples with RM, from 285 in 2003 to 990 in 2006 [7] and [8]. The current guidelines from this consortium do not give a recommendation in favor of or against PGS for couples with RM (9). On the other hand, the American Society of Reproductive Medicine guideline states that the available evidence does not support the use of PGS as currently performed to improve live birth rates in patients with recurrent pregnancy loss (10), because randomized control trials are not available. Because PGS is still being performed for this indication worldwide (8), we systemically searched the literature for the best available evidence on live birth rates and miscarriage rates after PGS and natural conception (NC) in couples with unexplained RM.

The following electronic databases were searched: MEDLINE (1950 to December 2009), EMBASE (1980 to December 2009), and the Cochrane Central Register of Controlled Trials (CENTRAL) (December 2009). A search strategy was carried out based on the following terms: recurrent miscarriage, preimplantation genetic screening, natural conception, live birth rate, and miscarriage rate (Supplemental Figure 1, Supplemental Table 1 and Supplemental Table 2, available online). The search was performed by a clinical librarian (J.L.). 
Musters, A.M., Repping, S., Korevaar, J.C., Mastenbroek, S., Limpens, J., Veen, F. van der, Goddijn, M. Pregnancy outcome after preimplantation genetic screening or natural conception in couples with unexplaine recurrent miscarriage: a systematic review of the best available evidence. Fertility and Sterility: 2011,95(6) 2153-2157

Unexplained RM was defined as two or more preceding - not necessarily consecutive - miscarriages ( $\leq 20$ weeks' gestational age) without an identified underlying cause (i.e., women with normal uterine cavities, negative for antiphospholipid syndrome, and normal parental karyotypes) (11).

We first searched for randomized control trials and/or comparative studies comparing PGS with NC in couples with unexplained RM. Subsequently, if these could not be found, a secondary search was performed in which we searched for cohort studies or randomized studies in which PGS or NC were compared with an intervention other than the one under investigation in this study. For NC, studies were only selected if the study included nonpregnant patients, to allow for a fair comparison with data from PGS studies. In addition, because PGS cycles are usually completed within as restricted a time frame as 1 year, we included NC studies with a follow-up duration of 1 year. Outcome measures were live birth rate per couple, defined as the percentage of couples for whom the pregnancy resulted in live birth, and miscarriage rate per couple, defined as the loss of a pregnancy before the 20th week of gestation.

As a first step, titles were screened. In addition, we hand-searched the reference lists of selected studies, of recent reviews on the subject, and the abstract books of the annual meetings of the American Society of Reproductive Medicine and the European Society of Human Reproduction and Embryology. The abstracts of the included titles were read. Next, full articles of the approved abstracts were read. The final selection of the studies was reached by consensus of two separate reviewers (A.M. and M.G.) after they had read the full articles. Any disagreement was settled by a third investigator (S.R.). In case published data was incomplete, corresponding authors were contacted for clarification.

We found no randomized controlled trials, nor did we find nonrandomized comparative studies in which PGS was directly compared with NC (primary search, Supplemental Fig. 1).

Because the aim of our review was to find the best available evidence, we performed a secondary search in which we searched for cohort studies or randomized studies in which PGS was compared with an intervention other than the one under investigation in this study. This search resulted in 196 publications on women with unexplained RM receiving PGS (secondary search, Supplemental Fig. 1 ([12-23, 26-63]\}(192 from electronic searchers, 3 from abstract books searched manually, 1 from reference lists of relevant publications). Of these, 157 were excluded because it was clear from the title that they did not fulfill the selection criteria. From the remaining 39 articles, 20 were excluded on the basis of the abstract. For the remaining 19 articles we obtained the full manuscripts; 15 were excluded (Supplemental Fig. 1). The total number of studies included in the review was therefore four $(5,6,24$ and 25) (Table 1).

The secondary search, in which we searched for cohort studies or randomized studies in which NC was compared with an intervention other than the one under investigation in this study, resulted in 2,272 publications (Supplemental Fig. 1) (2,272 from electronic searchers, 0 from reference lists of relevant publications). Of these, 2,187 publications were excluded because it was clear from the title that they did not fulfill the selection criteria. From the remaining 85 articles, 39 were excluded on the basis of the abstract. We obtained the full manuscripts of the remaining 46 articles; 39 articles were excluded. Therefore, a total of seven studies on NC were included (64-70) (Table 1).

The exact reasons for exclusion of the titles, abstracts, and full manuscripts are shown in Supplemental Fig. 1.

In the four observational studies concerning unexplained RM and PGS, the number of included couples was 181 and varied from 10 to 58 per study. The mean number of previous miscarriage varied between 2.8 and 4.7, and the mean maternal age varied from 35.4 to 37.6 years. In all studies the embryos were biopsied at day 3 of development, and one or two blastomeres were aspirated and analyzed. The fluorescence in situ hybridization (FISH) probes used for aneuploidy screening differed in each study (minimum of three and maximum of nine probes). Additionally, the number of embryos transferred varied per study; from singleembryo transfer to five embryos per transfer. There was an average of 1.3 cycles (range, $1.2-1.6$ cycles) per couple in the four studies.

Live birth rate per couple varied between $19 \%$ and $46 \%$ (mean $35 \%$; median $40 \%$ ), and miscarriage rate ranged from none to $10 \%$ (mean $9 \%$; median $9 \%$ ).

In the seven studies found for $\mathrm{NC}$ in RM couples the control arms of randomized controlled trials (comparing NC with any intervention other than PGS) and prospective cohorts were included. The patients in six of the seven studies received placebo treatment $(64-67,69,70)$. This varied from autologous blood 
injections to vaginal placebo pessaries to saline injections. In one study, patients used expectant management (68). The number of included couples was 261 and varied from 19 to 85 . The mean number of previous miscarriages varied between 3.0 and 5.6, and the mean maternal age varied from 25.1 to 34.6 years. The live birth rate ranged from $11 \%$ to $61 \%$ (mean $41 \%$; median $36 \%$ ), and the miscarriage rate ranged from $14 \%$ to $52 \%$ per couple (mean $28 \%$; median $25 \%$ ).

Our systematic search of the literature revealed no randomized controlled trials or nonrandomized comparative studies directly comparing the efficacy of PGS with NC for couples with unexplained RM. The need for randomized controlled trials on this topic is evident, considering the increasing numbers of PGS performed for this indication worldwide [7] and [8] .

A secondary search strategy, for the best available evidence, allowing other study comparisons or cohort studies on PGS and NC, provided data on a total of 442 couples (181 PGS and 261 NC).

The studies that were finally included have a number of limitations. The quality of the available data was low, owing to the limited number of observational studies, small sample sizes, and heterogeneity between studies. The heterogeneity among the PGS studies was considerable; the mean RM rate varied between 2.8 and 4.7; chromosomes tested per blastomere varied from three to nine, and the number of embryos transferred per cycle varied between one and five. There was also heterogeneity among the NC studies. The mean maternal age varied from 25.1 to 34.6 years, and in six of the seven included studies placebo treatment was administered to the patients because of the randomized controlled design of these studies. The heterogeneity between the two study groups, apart from receiving PGS or expectant management, was also apparent. The mean maternal age within studies varied almost 10 years; in the PGS studies maternal age varied between 35.4 and 37.6 years, whereas in the NC studies mean maternal age varied between 25.1 and 34.6 years.

Because of the above-mentioned heterogeneity between the PGS and NC studies, no meta-analysis could be performed, and as a result we can only summarize the data by tabulation and listing of ranges. When focusing on the data at hand, keeping in mind their low quality, a similar live birth rate is reported for PGS and NC (35\% and $42 \%$, respectively). The miscarriage rate for the PGS group (9\%) seems to be lower than in the NC group (28\%).

This review summarizes the best available evidence of the efficacy of PGS vs. NC. Live birth rates for PGS and NC groups are not very far apart, and the miscarriage rate after PGS may be lower. The need for comparative studies of high quality is urgent.

\section{[TABLE 1]}

\section{[FIGURE 1]}

\section{[TABLE 2]}

\section{[TABLE 3]}

\section{REFERENCES}

1.R. Rai and L. Regan, Recurrent miscarriage. Lancet, 368 (2006), pp. 601-611.

2.L. Gianaroli, M.C. Magli, A.P. Ferraretti, C. Tabanelli, C. Trombetta and E. Boudjema, The role of preimplantation diagnosis for aneuploidies. Reprod Biomed Online, 4 Suppl 3 (2002), pp. 31-36.

3.L. Werlin, I. Rodi, A. Decherney, E. Marello, D. Hill and S. Munné, Preimplantation genetic diagnosis as both a therapeutic and diagnostic tool in assisted reproductive technology. Fertil Steril, 80 (2003), pp. 467-468.

4.C. Rubio, T. Pehlivan, L. Rodrigo, C. Simón, J. Remohí and A. Pellicer, Embryo aneuploidy screening for unexplained recurrent miscarriage: a minireview. Am J Reprod Immunol, 53 (2005), pp. 159-165.

5.S. Munne, S. Chen, J. Fischer, P. Colls, X. Zheng and J. Stevens, et al. Preimplantation genetic diagnosis reduces pregnancy loss in women aged 35 years and older with a history of recurrent miscarriages. Fertil Steril, 84 (2005), pp. 331-335. 
Musters, A.M., Repping, S., Korevaar, J.C., Mastenbroek, S., Limpens, J., Veen, F. van der, Goddijn, M. Pregnancy outcome after preimplantation genetic screening or natural conception in couples with unexplaine recurrent miscarriage: a systematic review of the best available evidence. Fertility and Sterility: 2011, 9 2153-2157

6.A. Mantzouratou, A. Mania, E. Fragouli, L. Xanthopoulou, S. Tashkandi and K. Fordham, et al. Variable aneuploidy mechanisms in embryos from couples with poor reproductive histories undergoing preimplantation genetic screening. Hum Reprod, 22 (2007), pp. 1844-1853.

7.J.C. Harper, K. Boelaert, J. Geraedts, G. Harton, W.G. Kearns and C. Moutou, et al. ESHRE PGD Consortium data collection V: cycles from January to December 2002 with pregnancy follow-up to October 2003. Hum Reprod, 21 (2006), pp. 3-21.

8.V. Goossens, G. Harton, C. Moutou, P.N. Scriven, J. Traeger-Synodinos and K. Sermon, et al. ESHRE PGD Consortium data collection VIII: cycles from January to December 2005 with pregnancy follow-up to October 2006. Hum Reprod, 23 (2008), pp. 2629-2645.

9.A.R. Thornhill, C.E. de Die-Smulders, J.P. Geraedts, J.C. Harper, G.L. Harton and S.A. Lavery, et al. ESHRE PGD Consortium 'Best practice guidelines for clinical preimplantation genetic diagnosis (PGD) and preimplantation genetic screening (PGS)'. Hum Reprod, 20 (2005), pp. 35-48.

10.The Practice Committee of the Society for Assisted Reproductive Technology and the Practice Committee of the American Society of Reproductive Medicine, Preimplantation genetic testing: a Practice Committee opinion. Fertil Steril, 90 (2008), pp. S136-S146.

11.E. Jauniaux, R.G. Farquharson, O.B. Christiansen and N. Exalto, Evidence-based guidelines for the investigation and medical treatment of recurrent miscarriage. Hum Reprod, 21 (2006), pp. 2216-2222.

12.C. Simon, C. Rubio, F. Vidal, C. Gimenez, C. Moreno and J.J. Parrilla, et al. Increased chromosome abnormalities in human preimplantation embryos after in-vitro fertilization in patients with recurrent miscarriage. Reprod Fertil Dev, 10 (1998), pp. 87-92.

13.F. Vidal, C. Gimenez, C. Rubio, C. Simón, A. Pellicer and J. Santaló, et al. FISH preimplantation diagnosis of chromosome aneuploidy in recurrent pregnancy wastage. J Assist Reprod Genet, 15 (1998), pp. 310-313.

14.A. Pellicer, C. Rubio, F. Vidal, Y. Mínguez, C. Giménez and J. Egozcue, et al. In vitro fertilization plus preimplantation genetic diagnosis in patients with recurrent miscarriage: an analysis of chromosome abnormalities in human preimplantation embryos. Fertil Steril, 71 (1999), pp. 1033-1039.

15.C. Rubio, C. Simon, F. Vidal, L. Rodrigo, T. Pehlivan and J. Remohí, et al. Chromosomal abnormalities and embryo development in recurrent miscarriage couples. Hum Reprod, 18 (2003), pp. 182-188.

16.T. Pehlivan, C. Rubio, L. Rodrigo, J. Remohí, A. Pellicer and C. Simón, Preimplantation genetic diagnosis by fluorescence in situ hybridization: clinical possibilities and pitfalls. J Soc Gynecol Invest, 10 (2003), pp. 315-322. 17 C. Rubio, L. Rodrigo, I. Perez-Cano, A. Mercader, E. Mateu and P. Buendía, et al. FISH screening of aneuploidies in preimplantation embryos to improve IVF outcome. Reprod Biomed Online, 11 (2005), pp. 497-506.

18.M. Twisk, S. Mastenbroek, A. Hoek, M.J. Heineman, F. van der Veen and P.M. Bossuyt, et al. No beneficial effect of preimplantation genetic screening in women of advanced maternal age with a high risk for embryonic aneuploidy. Hum Reprod, 23 (2008), pp. 2813-2817.

19.C. Rubio, P. Buendía, L. Rodrigo, A. Mercader, E. Mateu and V. Peinado, et al. Prognostic factors for preimplantation genetic screening in repeated pregnancy loss. Reprod Biomed Online, 18 (2009), pp. 687-693.

20.S. Kahraman, M. Benkhalifa, E. Donmez, A. Biricik, S. Sertyel and N. Findikli, et al. The results of aneuploidy screening in 276 couples undergoing assisted reproductive techniques. Prenat Diagn, 24 (2004), pp. 307-311.

21.J. Garrisi, J. Cohen, K.M. Ferry, P. Colls, M.G. Garrisi and S. Munne, Preimplantation genetic diagnosis (PGD) effectively reduces idiopathic recurrent pregnancy loss (RPL) among patients with up to five previous miscarriages after natural conception, . Fertil Steril, 88 (2007) S85.

22.J.C. Harper, C. Die-Smulders, V. Goossens, G. Harton, C. Moutou and S. Repping, et al. ESHRE PGD consortium data collection VII: cycles from January to December 2004 with pregnancy follow-up to October 2005. Hum Reprod, 23 (2008), pp. 741-755.

23.J.G. Garrisi, P. Colls, K.M. Ferry, X. Zheng, M.G. Garrisi and S. Munne, Effect of infertility, maternal age, and number of previous miscarriages on the outcome of preimplantation genetic diagnosis for idiopathic recurrent pregnancy loss. Fertil Steril, 92 (2009), pp. 288-296.

24.M. Wilding, R. Forman, G. Hogewind, L. Di Matteo, F. Zullo and F. Cappiello, et al. Preimplantation genetic diagnosis for the treatment of failed in vitro fertilization-embryo transfer and habitual abortion. Fertil Steril, 81 (2004), pp. 1302-1307.

25.P. Platteau, C. Staessen, A. Michiels, A. Van Steirteghem, I. Liebaers and P. Devroey, Preimplantation genetic diagnosis for aneuploidy screening in patients with unexplained recurrent miscarriages. Fertil Steril, 83 (2005), pp. 393-397.

26.L. Levine, Habitual abortion. A controlled study of progestational therapy. West J Surg Obstet Gynecol, 72 (1964), pp. 30-36. 
Musters, A.M., Repping, S., Korevaar, J.C., Mastenbroek, S., Limpens, J., Veen, F. van der, Goddijn, M. Pregnancy outcome after preimplantation genetic screening or natural conception in couples with unexplaine recurrent miscarriage: a systematic review of the best available evidence. Fertility and Sterility: 2011, 9 2153-2157

27.J.W. Goldzieher, Double-blind trial of a progestin in habitual abortion. JAMA, 188 (1964), pp. 651-654.

28.E.R. Burton and E.G. Wachtel, A clinical trial and cytological assessment of enol Luteovis in the treatment of threatened and recurrent abortion. J Obstet Gynaecol Br Commonw, 74 (1967), pp. 533536.

29.J. Svigos, Preliminary experience with the use of human chorionic gonadotrophin therapy in women with repeated abortion. Clin Reprod Fertil, 1 (1982), pp. 131-135.

30.R.F. Harrison, Treatment of habitual abortion with human chorionic gonadotropin: results of open and placebo-controlled studies. Eur J Obstet Gynecol Reprod Biol, 20 (1985), pp. 159-168.

31.J.F. Mowbray, C. Gibbings and H. Liddell, Controlled trial of treatment of recurrent spontaneous abortion by immunisation with paternal cells. Lancet, 1 (1985), pp. 941-943.

32.M.N. Cauchi, D. Lim, D.E. Young, M. Kloss and R.J. Pepperell, Treatment of recurrent aborters by immunization with paternal cells-Controlled trial. Am J Reprod Immunol, 25 (1991), pp. 16-17.

33.H.N. Ho, T.J. Gill, H.J. Hsieh, J.J. Jiang, T.Y. Lee and C.Y. Hsieh, et al. Immunotherapy for recurrent spontaneous abortions in a Chinese population. Am J Reprod Immunol, 25 (1991), pp. 10-15.

34.O.B. Christiansen, B.S. Christiansen, M. Husth, C. Jersild and N. Grunnet, Prospective study of anticardiolipin antibodies in immunized and untreated women with recurrent spontaneous abortions. Fertil Steril, 58 (1992), pp. 328-334.

35.R.F. Harrison, Human chorionic gonadotrophin (hCG) in the management of recurrent abortion: results of a multi-centre placebo-controlled study. Eur J Obstet Gynecol Reprod Biol, 47 (1992), pp. 175-179.

36.P.A. Gatenby, K. Cameron, R.J. Simes, S. Adelstein, M.J. Bennett and R.P. Jansen, et al. Treatment of recurrent spontaneous abortion by immunization with paternal lymphocytes: results of a controlled trial. Am J Reprod Immunol, 29 (1993), pp. 88-94.

37.J. Collins and R. Roberts, Reports of independent analyses of data from the Worldwide Prospective Collaborative Study on immunotherapy for unexplained recurrent spontaneous abortion. Immunotherapy for recurrent spontaneous abortion: analysis 1. Am J Reprod Immunol, 32 (1994), pp. 275-280.

38.C.B. Coulam, Alternative treatment to lymphocyte immunization for treatment of recurrent spontaneous abortion. Immunotherapy with intravenous immunoglobulin for treatment of recurrent pregnancy loss. Am J Reprod Immunol, 32 (1994), pp. 286-289.

39.C.B. Coulam, Immunotherapy with intravenous immunoglobulin for treatment of recurrent pregnancy loss: American experience. Am J Reprod Immunol, 32 (1994), pp. 286-289.

40.O.B. Christiansen, O. Mathiesen, M. Husth, K.L. Rasmussen, H.J. Ingerslev and J.G. Lauritsen, et al. Placebo-controlled trial of treatment of unexplained secondary recurrent spontaneous abortions and recurrent late spontaneous abortions with i.v. immunoglobulin. Hum Reprod, 10 (1995), pp. 2690-2695.

41.C.B. Coulam, L. Krysa, J.J. Stern and M. Bustillo, Intravenous immunoglobulin for treatment of recurrent pregnancy loss. Am J Reprod Immunol, 34 (1995), pp. 333-337.

42.S. Quenby and R.G. Farquharson, Human chorionic gonadotropin supplementation in recurring pregnancy loss: a controlled trial. Fertil Steril, 62 (1994), pp. 708-710.

43.K. Clifford, R. Rai and L. Regan, Future pregnancy outcome in unexplained recurrent first trimester miscarriage. Hum Reprod, 12 (1997), pp. 387-389.

44.B. Jablonowska, A. Selbing, M. Palfi, S. Kjellberg and A.L. Selbing, Prevention of recurrent spontaneous abortion by intravenous immunoglobulin: a double-blind placebo-controlled study. Hum Reprod, 14 (1999), pp. 838-841.

45.H.J. Carp, V. Toder, E. Gazit, R. Ahiron, A. Torchinski and S. Mashiach, Further experience with intravenous immunoglobulin in women with recurrent miscarriage and a poor prognosis. Am J Reprod Immunol, 46 (2001), pp. 268-273.

46.O.B. Christiansen, B. Pedersen, A. Rosgaard and M. Husth, A randomized, double-blind, placebocontrolled trial of intravenous immunoglobulin in the prevention of recurrent miscarriage: evidence for a therapeutic effect in women with secondary recurrent miscarriage. Hum Reprod, 17 (2002), pp. 809816.

47.R. Rai, M. Backos, S. Elgaddal, A. Shlebak and L. Regan, Factor V Leiden and recurrent miscarriageprospective outcome of untreated pregnancies. Hum Reprod, 17 (2002), pp. 442-445.

48.H. Carp, M. Dolitzky and A. Inbal, Thromboprophylaxis improves the live birth rate in women with consecutive recurrent miscarriages and hereditary thrombophilia. J Thromb Haemost, 1 (2003), pp. 433438.

49.S. Dendrinos, E. Makrakis, D. Botsis, D. Chassiakos, S. Baka and G. Creatsas, A study of pregnancy loss in 352 women with recurrent miscarriages. Arch Gynecol Obstet, 271 (2005), pp. 235-239.

50.M.Y. El-Zibdeh, Dydrogesterone in the reduction of recurrent spontaneous abortion. J Steroid Biochem Mol Biol, 97 (2005), pp. 431-434. 
Musters, A.M., Repping, S., Korevaar, J.C., Mastenbroek, S., Limpens, J., Veen, F. van der, Goddijn, M. Pregnancy outcome after preimplantation genetic screening or natural conception in couples with unexplaine recurrent miscarriage: a systematic review of the best available evidence. Fertility and Sterility: 2011,95(6) 2153-2157

51.A.F. Amin, O.M. Shaaban and M.A. Bediawy, N-acetyl cysteine for treatment of recurrent unexplained pregnancy loss. Reprod Biomed Online, 17 (2008), pp. 722-726.

52.M. Fawzy, T. Shokeir, M. El-Tatongy, O. Warda, A.A. El-Refaiey and A. Mosbah. Arch Gynecol Obstet, 278 (2008), pp. 35-38.

53.A.M. Badawy, M. Khiary, L.S. Sherif, M. Hassan, A. Ragab and I. Abdelall. J Obstet Gynaecol, 28 (2008), pp. 280-284.

54.M.T. Illeni, G. Marelli, F. Parazzini, B. Acaia, L. Bocciolone and M. Bontempelli, et al. Immunotherapy and recurrent abortion: a randomized clinical trial. Hum Reprod, 9 (1994), pp. 1247-1249.

55.H. Carp, B. Feldman, G. Oelsner and E. Schiff, Parental karyotype and subsequent live births in recurrent miscarriage. Fertil Steril, 81 (2004), pp. 1296-1301.

56.T. Nonaka, K. Takakuwa, I. Ooki, M. Akashi, T. Yokoo and A. Kikuchi, et al. Results of immunotherapy for patients with unexplained primary recurrent abortions-prospective non-randomized cohort study. Am J Reprod Immunol, 58 (2007), pp. 530-536.

57.D.M. Gilchrist, J.E. Livingston, J.A. Hurlburt and R.D. Wilson, Recurrent spontaneous pregnancy loss. Investigation and reproductive follow-up. J Reprod Med, 36 (1991), pp. 184-188.

58.M. Diejomaoh, J. Jirous, M. Al-Azemi, S. Baig, M. Gupta and A. Tallat, The relationship of recurrent spontaneous miscarriage with reproductive failure. Med Princ Pract, 12 (2003), pp. 107-111.

59.H.J. Carp, Y. Hass, M. Dolicky, M. Goldenberg, S. Mashiach and J. Rabinovici, The effect of serum follicular phase luteinizing hormone concentrations in habitual abortion: correlation with results of paternal leukocyte immunization. Hum Reprod, 10 (1995), pp. 1702-1705.

60.H. Carp, M. Dolitzky, I. Tur-Kaspa and A. Inbal, Hereditary thrombophilias are not associated with a decreased live birth rate in women with recurrent miscarriage. Fertil Steril, 78 (2002), pp. 58-62.

61.H. Lashen, K. Fear and D.W. Sturdee, Obesity is associated with increased risk of first trimester and recurrent miscarriage: matched case-control study. Hum Reprod, 19 (2004), pp. 1644-1646.

62.M. Tulppala, T. Palosuo, T. Ramsay, A. Miettinen, R. Salonen and O. Ylikorkala, A prospective study of 63 couples with a history of recurrent spontaneous abortion: contributing factors and outcome of subsequent pregnancies. Hum Reprod, 8 (1993), pp. 764-770.

63.M. Dolitzky, A. Inbal, Y. Segal, A. Weiss, B. Brenner and H. Carp, A randomized study of thromboprophylaxis in women with unexplained consecutive recurrent miscarriages. Fertil Steril, 86 (2006), pp. 362-366.

64.O.B. Christansen, O. Mathiesen, M. Husth, J.G. Lauritsen and N. Grunnet, Placebo-controlled trial of active immunization with third party leukocytes in recurrent miscarriage. Acta Obstet Gynecol Scand, 73 (1994), pp. 261-268.

65.K. Clifford, R. Rai, H. Watson, S. Franks and L. Regan, Does suppressing luteinising hormone secretion reduce the miscarriage rate? Results of a randomised controlled trial. Br Med J, 312 (1996), pp. 15081511.

66.M.D. Stephenson, K. Dreher, E. Houlihan and V. Wu, Prevention of unexplained recurrent spontaneous abortion using intravenous immunoglobulin: a prospective, randomized, double-blinded, placebocontrolled trial. Am J Reprod Immunol, 39 (1998), pp. 82-88.

67.C. Ober, T. Karrison, R.R. Odem, R.B. Barnes, D.W. Branch and M.D. Stephenson, et al. Mononuclearcell immunisation in prevention of recurrent miscarriages: a randomised trial. Lancet, 354 (1999), pp. 365-369.

68.R. Ramhorst, E. Agriello, S. Zittermann, M. Pando, J. Larriba and M. Irigoyen, et al. Is the paternal mononuclear cells' immunization a successful treatment for recurrent spontaneous abortion?. Am J Reprod Immunol, 44 (2000), pp. 129-135.

69.M.K. Pandey and S. Agrawal, Induction of MLR-Bf and protection of fetal loss: a current double blind randomized trial of paternal lymphocyte immunization for women with recurrent spontaneous abortion. Intl Immunopharmacol, 4 (2004), pp. 289-298.

70.F. Scarpellini and M. Sbracia, Use of granulocyte colony-stimulating factor for the treatment of unexplained recurrent miscarriage: a randomised controlled trial. Hum Reprod, 24 (2009), pp. 27012708. 
Musters, A.M., Repping, S., Korevaar, J.C., Mastenbroek, S., Limpens, J., Veen, F. van der, Goddijn, M. Pregnancy outcome after preimplantation genetic screening or natural conception in couples with unexplaine recurrent miscarriage: a systematic review of the best available evidence. Fertility and Sterility: 2011, 2153-2157

\section{TABLES AND FIGURES}

\section{Table 1}

\begin{tabular}{|c|c|c|c|c|c|c|c|}
\hline \multicolumn{8}{|c|}{ Main results of included studies in fertile couples with unexplained recurrent miscarriages receiving PGS or conceiving naturally. } \\
\hline Study (reference) & Couples, $n$ & $\begin{array}{l}\text { Started } \\
\text { cycles, } n\end{array}$ & $\begin{array}{l}\text { OPU } \\
\text { cycles, n }\end{array}$ & $\begin{array}{c}E T \\
\text { cycles, } n\end{array}$ & $\begin{array}{l}\text { TE per cycle, } \\
\text { mean }\end{array}$ & $\begin{array}{l}\text { Live births, } \\
\text { n (\% per couple) }\end{array}$ & $\begin{array}{c}\text { Miscarriages, } \\
n \text { ( } \% \text { per couple) }\end{array}$ \\
\hline \multicolumn{8}{|l|}{ PGS } \\
\hline $\begin{array}{l}\text { Wilding et al." }{ }^{2}(24) \\
\text { 3 FISH probes: } 13,18,21\end{array}$ & 16 & - & 26 & - & 2.9 & $3(19)$ & - \\
\hline $\begin{array}{l}\text { Wilding et al." (24) } \\
5 \text { FISH probes: } 13,16,18,21,22\end{array}$ & 48 & - & 62 & - & 3.8 & $22^{\mathrm{b}}(46)$ & - \\
\hline $\begin{array}{l}\text { Platteau et al. (25) } \\
\text { FISH probes } 13,16,18,21,22, X, Y\end{array}$ & 49 & - & 69 & 49 & 2 & $10(20)$ & $5(10)$ \\
\hline $\begin{array}{l}\text { Munne et al. (5) } \\
\text { FISH probes: } 13,15,16,17,18,21 \text {, } \\
22, X, Y\end{array}$ & 58 & 69 & 69 & 60 & 2.3 & $25(43)$ & $5(9)$ \\
\hline $\begin{array}{l}\text { Mantzouratou et al. (6) } \\
\text { FISH probes: } 13,15,16,18,21,22\end{array}$ & 10 & 12 & 12 & 12 & $1.7^{\circ}$ & $4(40)$ & 0 \\
\hline Total & 181 & - & 238 & 121 & - & $64(35)$ & $10(9)$ \\
\hline \multicolumn{8}{|l|}{ NC } \\
\hline Christiansen et al. (64) & 26 & NA & NA & NA & NA & $10(39)$ & $11(42)$ \\
\hline Cilford et al. (65) & 31 & NA & NA & NA & NA & 19 (61) & $7(23)$ \\
\hline Stephenson et al. (66) & 30 & NA & NA & NA & NA & $10(33)$ & $8(27)$ \\
\hline Ober et al. (67) & 85 & NA & NA & NA & NA & $41(48)$ & $18(21)$ \\
\hline Ramhorst et al. (68) & 37 & NA & NA & NA & NA & $12(32)$ & $5^{\mathrm{d}}(14)$ \\
\hline Pandy et al. (69) & 19 & NA & NA & NA & NA & $2(11)$ & $6(32)$ \\
\hline Scarpellini et al. (70) & 33 & NA & NA & NA & NA & $16(48)$ & $17(52)$ \\
\hline Total & 261 & & & & & $110(42)$ & $72(28)$ \\
\hline \multicolumn{8}{|c|}{ 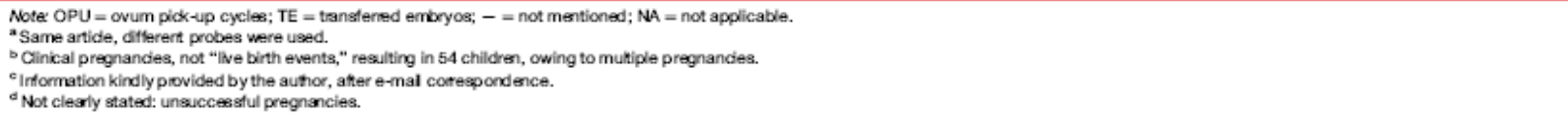 } \\
\hline Musters Carrespowdence. Feril Seril 2011. & & & & & & & \\
\hline
\end{tabular}


Musters, A.M., Repping, S., Korevaar, J.C., Mastenbroek, S., Limpens, J., Veen, F. van der, Goddijn, M. Pregnancy outcome after preimplantation genetic screening or natural conception in couples with unexplaine recurrent miscarriage: a systematic review of the best available evidence. Fertility and Sterility: 2011, 2153-2157

\section{Figure 1}

\section{SUPPLEMIENTAL FIGURE 1}

Flow chart: inclusion of studies.

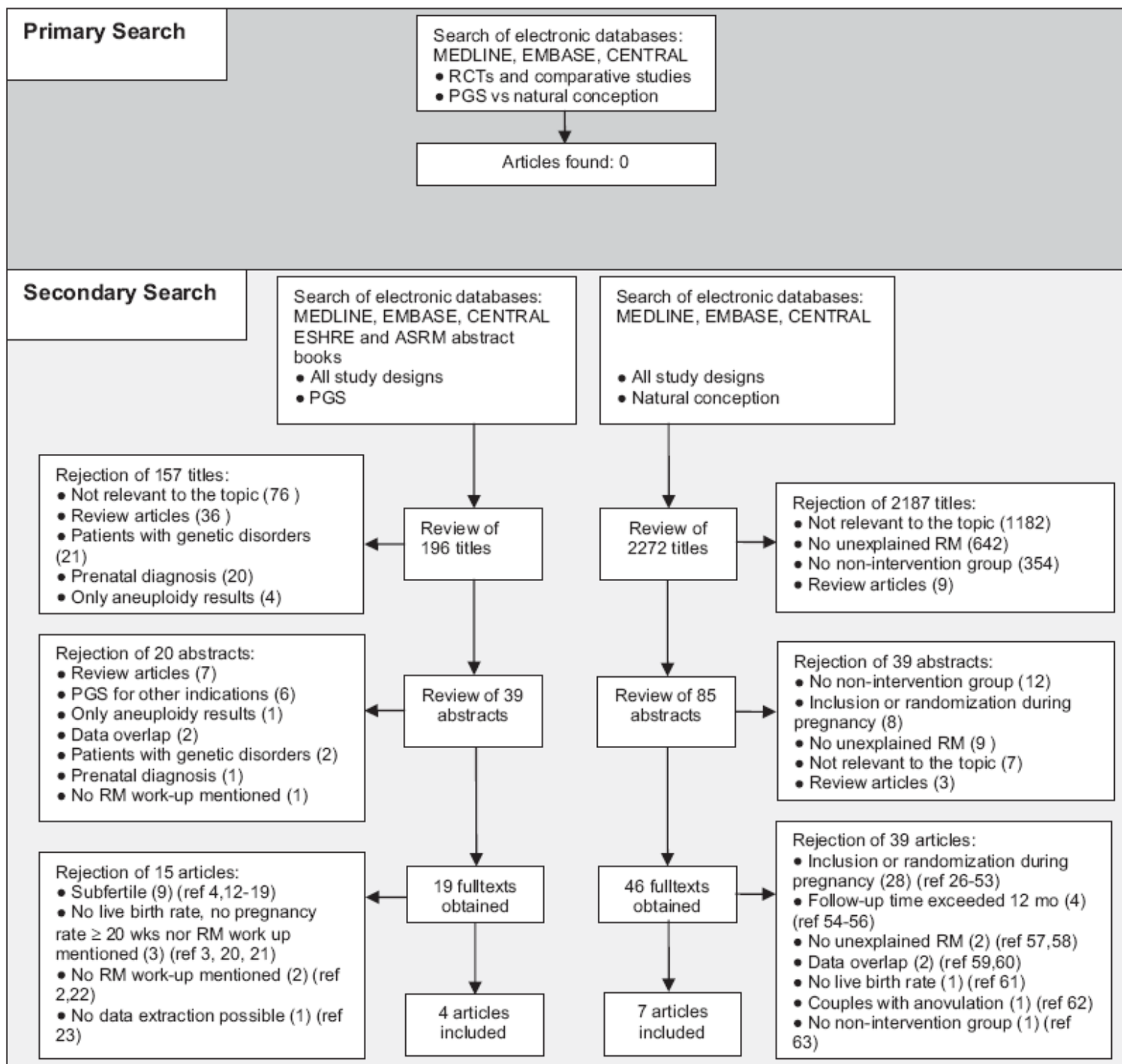

Musters. Correspondence. Fertil Steril 2011 
Musters, A.M., Repping, S., Korevaar, J.C., Mastenbroek, S., Limpens, J., Veen, F. van der, Goddijn, M. Pregnancy outcome after preimplantation genetic screening or natural conception in couples with unexplaine recurrent miscarriage: a systematic review of the best available evidence. Fertility and Sterility: 2011, 2153-2157

Table 2

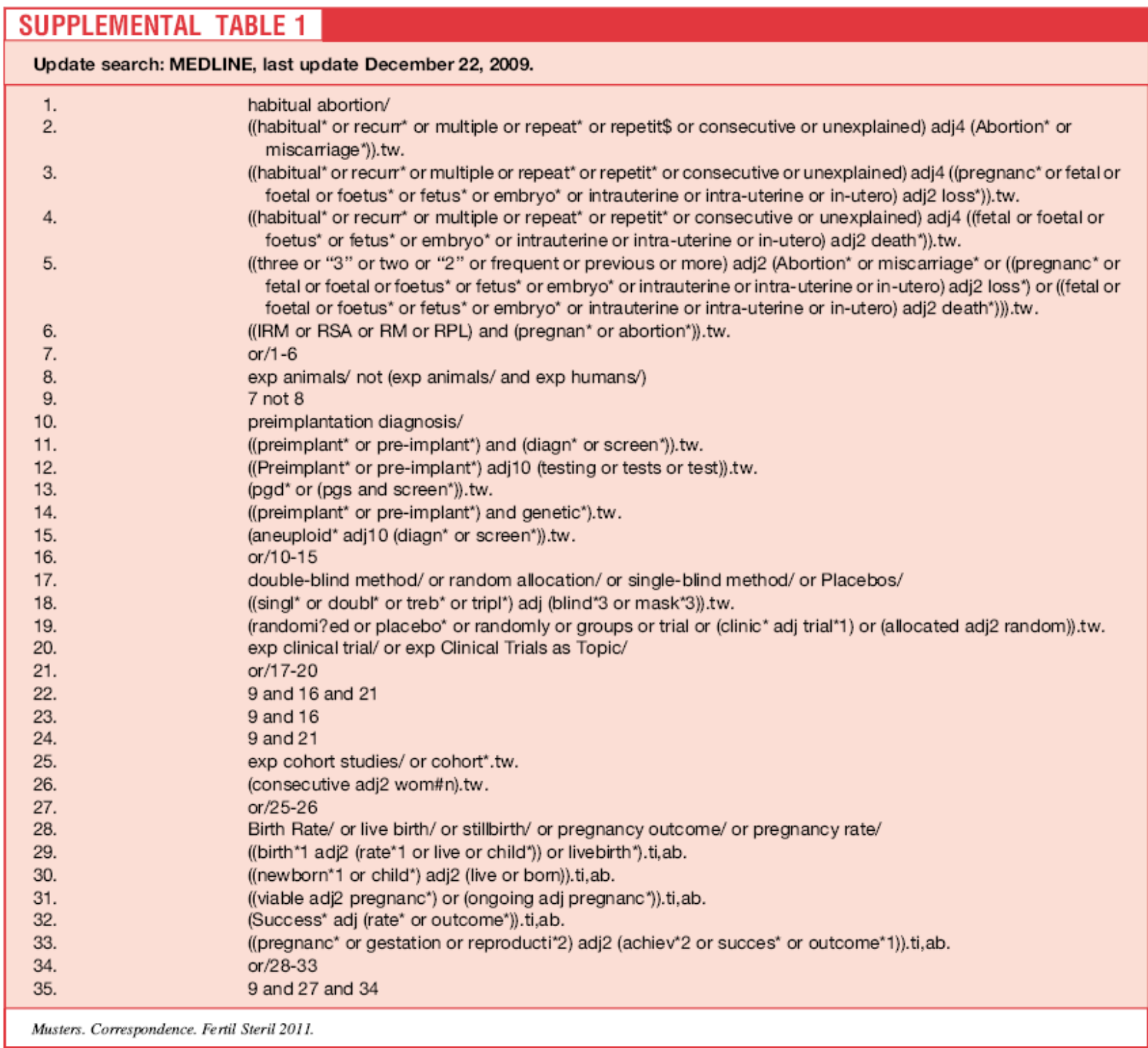


Musters, A.M., Repping, S., Korevaar, J.C., Mastenbroek, S., Limpens, J., Veen, F. van der, Goddijn, M. Pregnancy outcome after preimplantation genetic screening or natural conception in couples with unexplaine recurrent miscarriage: a systematic review of the best available evidence. Fertility and Sterility: 2011,95(6) 2153-2157

Table 3

\begin{tabular}{|c|c|}
\hline \multicolumn{2}{|c|}{ Update search: EMBASE, last update December 22, 2009.} \\
\hline 1. & recurrent abortion/ or ((Spontaneous Abortion/ or fetal wastage/) and Recurrent Disease/) \\
\hline 2. & $\begin{array}{l}\text { ((habitual* or recurr* or multiple or repeat* or repetit\$ or consecutive or unexplained) adj4 (Abortion* or } \\
\text { miscarriage }) \text { ).tw. }\end{array}$ \\
\hline 3. & $\begin{array}{l}\text { ((habitual }{ }^{\star} \text { or recurr }{ }^{\star} \text { or multiple or repeat* or repetit* or consecutive or unexplained) adj4 ((pregnanc }{ }^{\star} \text { or fetal or } \\
\left.\text { foetal or foetus }{ }^{\star} \text { or fetus }{ }^{\star} \text { or embryo* or intrauterine or intra-uterine or in-utero) adj2 loss }{ }^{\star}\right) \text { ).tw. }\end{array}$ \\
\hline 4. & $\begin{array}{l}\text { ((habitual }{ }^{\star} \text { or recurr* or multiple or repeat }{ }^{\star} \text { or repetit* or consecutive or unexplained) adj4 ((fetal or foetal or } \\
\left.\text { foetus }{ }^{\star} \text { or fetus }{ }^{\star} \text { or embryo* or intrauterine or intra-uterine or in-utero) adj2 death }\right) \text { ).tw. }\end{array}$ \\
\hline 5. & $\begin{array}{l}\text { ((three or " } 3 \text { " or two or "2" or frequent or previous or more) adj2 (Abortion" or miscarriage }{ }^{\star} \text { or ((pregnanc }{ }^{\star} \text { or } \\
\text { fetal or foetal or foetus }{ }^{\star} \text { or fetus" or embryo* or intrauterine or intra-uterine or in-utero) adj2 loss") or ((fetal or } \\
\text { foetal or foetus" or fetus" or embryo* or intrauterine or intra-uterine or in-utero) adj2 death"))).tw. }\end{array}$ \\
\hline 6. & $(($ IRM or RSA or RM or RPL) and (pregnan* or abortion*)).tw. \\
\hline 7. & or/1-6 \\
\hline 8. & limit 7 to humans \\
\hline 9. & $\left(\left(\right.\right.$ preimplant $^{\star}$ or pre-implant $\left.{ }^{*}\right)$ and $\left(\right.$ diagn $^{\star}$ or screen $\left.)\right) . t w$. \\
\hline 10. & ((Preimplant ${ }^{\star}$ or pre-implant $\left.{ }^{\star}\right)$ adj10 (testing or tests or test)).tw. \\
\hline 11. & $\left(\mathrm{pgd}^{\star}\right.$ or $\left(\mathrm{pgs}\right.$ and screen $\left.\left.{ }^{\star}\right)\right) \cdot \mathrm{tw}$. \\
\hline 12. & ((preimplant* or pre-implant") and genetic $\left.{ }^{*}\right) . t w$. \\
\hline 13. & (aneuploid ${ }^{\star}$ adj10 (diagn* or screen $\left.{ }^{\star}\right)$ ).tw. \\
\hline 14. & or/9-13 \\
\hline 15. & 8 and 14 \\
\hline 16. & prenatal diagnosis/ or genetic screening/ or prenatal screening/ \\
\hline 17. & exp autosome/ or exp sex chromosome/ \\
\hline 18. & fluorescence in situ hybridization/ or FISH.tw. \\
\hline 19. & chromosome aberration/ or aneuploidy/ \\
\hline 20. & embryo.mp. \\
\hline 21. & or/17-20 \\
\hline 22. & exp controlled study/ or cohort.mp. \\
\hline 23. & birth rate/ or fetus outcome/ or pregnancy outcome/ or pregnancy rate/ or childbirth/ or progeny/ \\
\hline 24. & or/22-23 \\
\hline 25. & 8 and 16 and 21 and 24 \\
\hline 26. & 15 or 25 \\
\hline 27. & exp controlled clinical trial/ or double blind procedure/ or single blind procedure/ or randomization/ or placebo/ \\
\hline 28. & (randomized and controlled and trial).ti,ab. \\
\hline 29. & ((controlled adj (trial or study)) or (controlled adj clinical adj (trial or study))).ti,ab. \\
\hline 30. & or/27-29 \\
\hline 31. & 8 and 26 and 30 \\
\hline 32. & 8 and 30 \\
\hline 33. & $\begin{array}{l}\text { "parameters concerning the fetus, newborn and pregnancy"/ or birth rate/ or fetus heart rate/ or fetus } \\
\text { mortality/ or fetus outcome/ or live birth/ or pregnancy outcome/ or pregnancy rate/ or child birth/ or } \\
\text { progeny/ }\end{array}$ \\
\hline 34. & ((birth*1 adj2 (rate*1 or live or child*)) or livebirth*).ti,ab. \\
\hline 35. & ((newborn*1 or child*) adj2 (live or born)).ti,ab. \\
\hline 36. & ((viable adj2 pregnanc*) or (ongoing adj pregnanc $\left.\left.{ }^{\star}\right)\right)$.ti,ab. \\
\hline 37. & $\left(\right.$ Success ${ }^{\star}$ adj $\left(\right.$ rate $^{\star}$ or outcome $\left.)\right) \cdot$ ti, ab. \\
\hline 38. & ((pregnanc ${ }^{\star}$ or gestation or reproducti^2) adj2 (achiev² or succes ${ }^{\star}$ or outcome $\left.\left.{ }^{\star} 1\right)\right)$.ti,ab. \\
\hline 39. & or $/ 33-38$ \\
\hline 40. & cohort analysis/ or cohort.tw. \\
\hline 41. & (consecutive wom\#n or consecutive nonpregnant wom\#n). tw. \\
\hline 42. & Iongitudinal study/ or prospective study/ \\
\hline 43. & or/40-42 \\
\hline 44. & 8 and 39 and 43 \\
\hline 45. & 8 and $(14$ or (16 and 21 and 24$))$ \\
\hline
\end{tabular}

